\title{
The Evaluation of Antibiotics Using to Pediatric Acute Upper Respiratory Tract Infection Patients at Health Centers in Kunduran Blora 2013
}

\author{
Tesar Zumi Antoro and Nurul Mutmainah \\ Faculty of Pharmacy Universitas Muhammadiyah Surakarta \\ Street A. Yani Tromol Pos I, Pabelan Kartasura Surakarta 57102 \\ e-mail : tesarzulant@gmail.com
}

\begin{abstract}
Acute respiratory tract infection is an acute infection which attacks one or more part of respiratory tract from nose to alveoli. This disease is an important society's health problem especially in the developing countries which attacks children easily especially who have low body's immunity. This aim of the research was to know representation of the treatment and the accuracy of antibiotics distribution as the treatment of pediatric patients of acute upper respiratory tract infection (AURTI) at Health Center in Kunduran, Blora 2013 which is observed by appropriate parameter indication, appropriate drugs, appropriate dose and appropriate patients using the standard from WHO (2003). This research was categorized as qualitative and non experimental research. In obtaining the data, the researcher trace the pediatric patient's medical record in the registration book in the health center Kunduran, Blora regency year 2013. The obtained data was analyzed descriptively to evaluate the rationality of antibiotics distribution for AURTI. The research result showed that over 110 of the available samples in children aged up to 12 years old which were diagnosed as AURTI sufferer, 92 cases (83.63\%) used amoxicillin antibiotics, 18 cases (16.37\%) used kotrimoksazol, 72 cases (65.50\%) were proper indication, 59 case (53.63\%) were proper drugs, 110 cases (100\%) were proper patients, 87 case (79.09\%) were proper dose, and 47 case (42.70) were rational in the treatment
\end{abstract}

Keywords: AURTI, Medication Evaluation, Health Centers, Pediatric patients, Antibiotics.

\begin{abstract}
Abstrak
Infeksi Saluran Pernapasan Akut merupakan infeksi akut yang menyerang satu atau lebih dari saluran pernapasan mulai dari hidung sampai alveoli. Penyakit ini merupakan masalah kesehatan masyarakat yang penting terutama pada negara berkembang dan sangat mudah menyerang pada anak yang masih memiliki sistem imunitas tubuh yang rendah. Penelitian ini bertujuan untuk mengetahui gambaran terapi dan ketepatan pemberian antibiotik untuk terapi ISPaA pada anak di puskesmas Kunduran Kabupaten Blora tahun 2013 di tinjau dari parameter tepat indikasi, tepat obat, tepat dosis dan tepat pasien dengan standar pedoman dari WHO tahun 2003.Penelitian ini merupakan kategori kualitatif dan bersifat non eksperimental. Jenis data dilakukan dengan melakukan penelusuran catatan pengobatan dalam buku registrasi pasien anak di puskesmas Kunduran Kab. Blora tahun 2013. Data yang diperoleh dianalisis secara deskriptif untuk mengevaluasi kerasionalan pemberian antibiotik untuk ISPaA. Hasil penelitian menunjukan bahwa dari 110 sampel pada anak usia sampai 12 tahun yang terdiagnosa ISPaA, 92 kasus $(83,63 \%)$ menggunakan antibiotik amoksisilin dan 18 kasus (16,37\%) menggunakan antibiotik kotrimoksazol, 72 kasus $(65,50 \%)$ tepat indikasi, 59 kasus (53.63\%) tepat obat, 110 kasus (100\%) tepat pasien, 87 kasus (79,09\%) tepat dosis, serta hanya 47 kasus $(42,70 \%)$ yang sudah rasional dalam terapinya.
\end{abstract}

Kata kunci: ISPaA, Evaluasi Pengobatan, Puskesmas, Pasien anak, Antibiotik

\section{Introduction}

In the development countries, infection disease is still being the important society's health problem. Antibiotics is the most frequently medicine uses for infection. Some of the research findings showed that 40 up to $60 \%$ antibiotics are used improperly into the disease which doesn't need antibiotics treatment. In the other research about the quality of antibiotics using found that $30 \%$ up to $80 \%$ antibiotics using are not based on available indication (Hadi, 2009).

The success of antibiotics using is determined by the using and the electing 
antibiotics treatment. The proper and rational use of antibiotics can avoid resistance, but the improper using of antibiotics can affect bacteria resistance toward the existence antibiotics. The use of other medicines might increase Drug Related Problems (DRPs). Related to DRPs, each pharmacist must be able to detect, overcome, and prevent the occurring problems or the future problems in the management and antibiotics using (Worokarti, 2005).

Indonesia which is located in tropical area is very potential to be endemic area of some infection diseases which can be a serious problem for society's health. The effect of geographies can be the main aspect in the increasing of the case or the death caused by AURTI, for example pollution which are caused by smokes of forest conflagration, the residue of the gas comes from the transportation tools, and air pollution inside house caused by smoke of the kitchen, smoke of the cigarettes, global climates changing such as air temperature changing, humidity, the fall of rain are health's threat especially AURTI (Daroham\&Mutiatikum, 2009).

Acute respiratory tract infection (ARTI) is upper or under respiratory disease, commonly spread and causes some spectrum diseases from the disease without symptoms or light infection to diseases with serious condition and deathly. It depends on the causing pathogen, environment, and the offering factor (WHO, 2007).

ARTI is causing death to the children in the small number. While under respiratory infection is causing death to the children in the larger number, but AURTI is causing disablement to the children. In the development countries, otitis medium is the cause of deafness to the children which is able to be prevented and a significant contributor toward the development and studying problem of the children (WHO, 2003).
The research which was done by Hapsari and Astuti on 2007 at Health center of Purwareja, Klampok, Banjarnegara showed that the most frequent antibiotic was kotrimoksazol $(86.7 \%)$, while amoxicillin was less (13.3\%). Kotrimoksazol used more in respiratory infection because it was the first option of medicine rather than amoxicillin (Hapsari\&Atuti, 2007).

\section{Research Methodology}

\section{Category and Research Program}

The research was a non experimental and qualitative research. Data was obtained retrospectively by tracing medical record in the registration book to pediatric patient diagnosed AURTI in Health Center of Kunduran by year 2013. The obtained data was analyzed descriptively which evaluated the rationality of antibiotics using for the AURTI treatment for the children. The materials used in this research were guidelines from WHO by year 2003 .

\section{Sample Decision}

Sampling technique was done by purposive sampling. Sample was the part of population which fulfills inclusion criteria. Inclusion criteria were as follows:
a. Patient with AURTI diagnose.
b. Pediatric patients $(<12$ years old $)$
c. Patient who got antibiotics treatment.

The following was the formula to calculate and decide the amount of sample:

$$
N=p \cdot q\left(Z_{1 / 2 \alpha} / b\right)^{2}
$$

Where:

$\mathrm{N}=$ Minimum amount of sample

$\mathrm{P}=$ The proportion of percentage the first population group

$\mathrm{Q}=$ The proportion of percentage the first population group or proportion of the reduction $(1-p)$ 
$Z_{1 / 2 \alpha}=$ The degree of condense coefficient in the certain trust tariff (95 or 99\%)

$\mathrm{B}=$ Percentage of the estimation of the probable mistakes in the sample decision $(0.1-0.5)$

So, the researcher got assumption where the value of $p$ and $q$ were same that's 0.5 If $p$ $=0.5$, so $q=1-0.5=0.5$

$\mathrm{N} \geq \mathrm{p} . \mathrm{q}\left(\mathrm{Z}_{1 / 2 \alpha} / \mathrm{b}\right)^{2}$

$\mathrm{N}=0.5 \times 0.5\left(\mathrm{Z}_{1 / 2 a} / \mathrm{b}\right)^{2}$

$\mathrm{N}=90.25 \approx 90$

So the minimum amount of the sample was 90 patients. (Nawawi, 2005).

\section{Data Analysis}

All submitted data during the research categorized based on the types of antibiotics, the dose and the frequency of the distribution of the antibiotics and calculated the percentage of proper indication, proper medicine, proper patient, proper dose, and also the rationality of the treatment as a whole. All data compared with the guidelines from WHO year 2003.

\section{Result And Discussion}

During 2013, the number of the patient diagnosed as AURTI sufferer in Health Centre in Kunduran, Blora was 1853 patient. The research had done by taking 110 samples from the nursing of pediatric in Health Centre in Kunduran, Blora. The taken data covered characteristic of the patient which fulfills the inclusion requirement (pediatric patient, diagnosed as AURTI sufferer, got antibiotics treatment) from the research sample.

\section{Patient Characteristic}

The samples taken in this research have some various characteristics. Those characteristics include gender, age, diagnose and symptoms felt by the patient. Table 1 explained the characteristic of the patient.

a. Based on the gender

Based on the result on Table 1, the number of boys patient was larger than the girls. The amount ofboys were 57 patients $(51.82 \%)$ and the girls were 53 patients $(48.18 \%)$.

b. Based on the age

Pediatric patient were the patient who needs special treatment because in determining the dose the practitioner will consider the weight and also the immunity system of the children which still weak.

From the taken sample, the most samples was the children under five $(62.73 \%)$ because in this age the growth system improves so fast so there were so many activities done by the children with the low immune system that would make the children affected by AURTI easily (Kemenkes RI, 2010).

c. Based on the diagnose

AURTI include influenza, pharynxitis, sinusitis, and otitis medium (Said, 1994), obtained diagnose as influenza, pharynxitis and sinusitis. From 110 diagnosed of AURTI of the children in Kunduran Health Center during 2013, there were 38 patients (34.54\%) diagnosed as influenza, 71 patients $(64.55 \%)$ diagnosed as pharynxitis and only 1 patient $(0.91 \%)$ diagnosed as sinusitis.

d. Based on the symptoms

AURTI comes commonly along with the various symptoms, the research result showed that fever and cough were the most common symptoms of AURTI, then followed by queasy and vomit but the symptoms had less prevalence rather than fever and cough. 
Table 1. Characteristic of the pediatric patient of AURTI in Health Centre, Kunduran, Blora year 2013.

\begin{tabular}{cccc}
\hline \multicolumn{2}{c}{ Eplanation } & Number & $\begin{array}{c}\text { Percentage } \\
(\%)\end{array}$ \\
\hline Gender & Boy & 57 children & $51,82 \%$ \\
Age & Girl & 53 children & $48,18 \%$ \\
Baby $(0-12$ month) & 7 children & $6,37 \%$ \\
Pre-school (5-6 year) & 69 children & $62,73 \%$ & \\
School (6-12 year) & 17 children & $15,45 \%$ & \\
Diagnose & 17 children & $15,45 \%$ & \\
Sinusitis & Influenza & 38 patients & $34,54 \%$ \\
& Pharynxitis & 71 patients & $64,55 \%$ \\
Symptoms & 1 patients & $0,91 \%$ & \\
Nausea and vomiting & Fever & 104 patients & $94,54 \%$ \\
& 14 patients & $12,72 \%$ & \\
\hline
\end{tabular}

e. Treatment Characteristic

The realization of the treatment of AURTI especially for pediatric patients mostly used antibiotics, but there were also some didn't need antibiotics. Non antibiotics treatment was also needed to be given to reduce and cure the symptoms that came along AURTI. Table 2 gave the characteristic in AURTI treatment for pediatric patients in Kunduran Health centre, Blora, by 2013.

Table 2. Characteristic of AURTI treatment for pediatric patients in Kunduran Health Centre, Blora Year 2013

\begin{tabular}{|c|c|c|c|}
\hline Treatment Class & $\begin{array}{c}\text { The name of the } \\
\text { medicine }\end{array}$ & Number & Percentage (\%) \\
\hline Antibiotics & Amokxicilin & 92 case & $83,63 \%$ \\
\hline $\begin{array}{l}\text { Kotrimoksazol } \\
18 \text { case }\end{array}$ & \multicolumn{2}{|c|}{$16,37 \%$} & \\
\hline Antipyretic analgesic & Paracetamol & 104 case & $94,54 \%$ \\
\hline Antihistamines & CTM & 98 case & $89,09 \%$ \\
\hline Corticosteroids & Dexamethason & 17 case & $15,45 \%$ \\
\hline Expectorant & Ambroksol & 6 case & $5,45 \%$ \\
\hline $\begin{array}{c}\text { Glyserin Guiakolat } \\
89 \text { case }\end{array}$ & \multicolumn{2}{|c|}{$80,90 \%$} & \\
\hline $\mathrm{OBH}$ & \multicolumn{2}{|c|}{$1,81 \%$} & \\
\hline Antiinfluenza & Fludane Sirup & 5 case & $4,54 \%$ \\
\hline Maag & Antasida & 14 case & $12,72 \%$ \\
\hline Vitamin & Vitamin C & 7 case & $6,36 \%$ \\
\hline $\begin{array}{c}\text { Vitamin B complex } \\
4 \text { case }\end{array}$ & \multicolumn{2}{|c|}{$3,63 \%$} & \\
\hline $\begin{array}{l}\text { Recovit } \\
3 \text { case }\end{array}$ & \multicolumn{2}{|c|}{$2,72 \%$} & \\
\hline
\end{tabular}

f. Antibiotics

AURTI is the disease caused by virus and bacteria. So, the treatments have to hamper the growth and kill both bacteria and virus by giving antibiotics. Antibiotics used in Kunduran Health centre for the treatment of AURTI for pediatric patient in 2013 were amoxicillin and kotrimoksazol. The most frequent antibiotics were amoxicillin $(83.63 \%)$ and kotrimoksazol (16.37\%). 
g. Non antibiotics medicine

The medicine used for AURTI treatment for the pediatric patient was not only antibiotics but there were various medicines used to cure the symptoms, and the most frequent non antibiotics medicine was paracetamol (94.54\%). It's because almost all the AURTI pediatric patient suffering fever and feel unhealthy so they need paracetamol. CTM was given as the supported treatment for AURTI if the patients suffering influenza. CTM was the second most frequence medication after paracetamol (89.09\%). The use of gliseringuaicolate, ambroxol and $\mathrm{OBH}$ were able to dilute the phlegm in the cough symptoms. The use of antacid actually doesn't aim for AURTI treatment, but for the patient who suffering vomits so antacid was given to protect the gastric of the patient. The use of dexamathasone was for the patient who suffering bad coughs and asthma. The symptoms was indicated by secondary infection so the practitioner in health centre gave dexamethasone to overcome the symptoms.

h. Antibiotics evaluation

AURTI is caused by bacteria or virus except for those who diagnosed as influenza sufferer. The use of antibiotics treatment was needed to obstruct the growth and kill AURTI bacteria. The use of antibiotics properly and rationally would determine the quality of the treatment and on the contrary would cause side effect especially the resistance which recently there were so many cases about antibiotics resistance because of improper use of antibiotics (Warsaetc, 1990).

i. Proper indication

Proper indication is the conformity of the implementation toward the indication of AURTI. There were
72 patients $(65.50 \%)$ were proper indication and 38 patients $(34.50 \%)$ were in improper indication. 72 patients with proper indication were patient with pharynxitis and sinusitis diagnose then the implementation of the treatment uses antibiotics. There were 37 patients with improper indication because of the patient's diagnosed was influenza. Influenza didn't use antibiotics as the treatment but paracetamol was enough (WHO, 2003). Influenza has character of self-limiting so the use of antibiotics was no need for influenza treatment. But, the practitioner in health center stated that the distribution of antibiotics for the influenza sufferer was often to be done if the patients suffering bad cough symptoms, high fever so if the patients didn't get any antibiotics, it would be under respiratory infection. The pediatric patient who came to the health centre with cough and flu symptoms commonly would come back to the health centre because they didn't get any antibiotics before.

\section{Proper medication}

a. The choosing of proper medication would affect the success of the treatment. Table 2 provided the number of proper drugs distribution based on the indication compared to WHO standard 2003. In this treatment for pediatric patients, there were 59 cases $(53.63 \%)$ which were already proper medication and 51 cases $(46.37 \%)$ were improper medication. There were some factors which affect improper medication, they were: The use of antibiotic on the influenza diagnose and kotrimoksazol distribution for those who had pharynxitis diagnose because the first line antibiotic for pharynxitis was amoxicillin. Kotrimoksazol is not suggested 
for pharynxitis that caused by streptococcus (WHO, 2003).

b. Proper patient

In this research, the implementation of AURTI for pediatric patients was based on the guidelines of WHO year 2003. The distribution of antibiotics included amoxicillin and kotrimoksazol didn't affect contraindication to the pediatric patients. So for the result of the proper patient's parameter was $100 \%$, because there was no contraindication of the medicine with patient's condition.

c. Proper dose

One of the important factors of the success of infection treatment using antibiotics was dose. Dose is an important factor in determining the quality of the treatment. If there was excess dose, it would cause toxicity and side effect. While if the dose was less, it would cause the healing process worked not maximize.

The obtained dose from this research was compared with the standard dose which exists in the guidelines from WHO year 2003. In determining the dose for the children should really pay attention because it depends on weight of the children, not to the age of th children as alike adult, so for the proper dose there was much mistakes, because of the various condition of the patients so the practitioner gave dose based on the condition of the patients.

The analysis of proper dose parameter was done through comparing the dose of drugs distribution with the standard from WHO year 2003. The researcher didn't analyze the duration of the distribution of antibiotics because of the limit of the available medicine and for the controlling of expending medicine of the health centre so the distribution of the medicine was only for 3 to 4 days. The distribution of antibiotics in short time could cause resistance, but the medical practitioner in health centre will inform to the patient to come back if there was no change during those 3 to 4 days.

d. The result of the analysis showed that 87 cases $(79.09 \%)$ were already proper dose and 23 cases $(20.91 \%)$ were improper dose. From 23 cases of improper dose, there were 17 cases which were underdose so the treatment process will not maximize and 6 case overdose which was able to make tocicity for the body.

e. Treatment rationality

This parameter covered all the analyzed parameter that were proper indication, proper medication, proper dose and proper patient. The result of the analysis showed that 47 cases $(42.70 \%)$ were already rational in the treatment based on the proper indication parameter, proper medication, proper patient and proper dose.

\section{Conclusion}

The most frequent antibiotics used in AURTI were amoxicillin 92 case (83.63\%) and kotrimoksazol by 18 case $(16.37 \%)$.

There were 73 cases $(65.50 \%)$ proper indication, 59 cases $(53.63 \%)$ proper medication, 110 cases $(100 \%)$ proper patients, 87 cases $(79.09 \%)$ proper dose, and only 47 cases $(42.70 \%)$ that already rational.

\section{Reference}

Daroham, N.E.P. \& Mutiatikum, 2009, Penyakit ISPA Hasil Riset Kesehatan Dasar (Riskerdas) di Indonesia, Puslitbang Biomedis dan Farmasi Jakarta, 50-55

Hadi, U., 2009, Resistensi Antibiotik : Buku Ajar Ilmu Penyakit Dalam, V, Jakarta, Interna 
Publishing

Hapsari, I. \& Astuti, I.W.B., 2007, Pola Penggunaan Antibiotika pada Infeksi Saluran Pernapasan Akut Pneumonia Balita pada Rawat Jalan Puskesmas Purwareja I klampok Kabupaten Banjarnegara Tahun 2004, Pharmacy, 05, 49-56

KemenKes RI, 2010, Pedoman Kader Seri Kesehatan Anak, Jakarta, Direktorat Bina Kesehatan Anak

KemenKes RI, 2012, Pedoman Pengendalian Infeksi Saluran Pernapasan Akut, Jakarta, Kementrian Kesehatan Republik Indonesia

Nawawi, H., 2005, Metode Bidang Sosial, Yogyakarta, Gajah Mada University Press

Warsa, U.C., Josodiwondo, S., Rahim, A \& Santoso, A.U.S., 1990, Penggunaan Antibiotik Secara Rasional dan Masalah Resistensi Kuman, Kumpulan Makalah Seminar : Pemilihan dan Pemakaian Antibiotik Dalam Klinik. Yogyakarta, Yayasan Melati Nusantara FK UGM

WHO, 2007, Pencegahan dan Pengendalian Infeksi Saluran Pernapasan Akut (ISPA) yang Cenderung Menjadi Epidemi dan Pandemi di Fasilitas Pelayanan Kesehatan, Jenewa, WHO Interim Guidline.

WHO, 2003, Penanganan ISPA pada Anak di Rumah Sakit Kecil Negara Berkembang, diterjemahkan oleh Susi, N. 2-17, Jakarta, World Health Organization

Worokarti, 2005, Peran Farmasis Dalam Pengelolaan Penderita Penyakit Infeksi Untuk Mencegah Timbulnya Resistensi Antimikroba, Naskah Lengkap Simposium Penyakit Infeksi dan Problema Resistensi Antimikroba, 55-69, Surabaya, Amrin Study Group and Infectious Disease Centre dan FKUA RSU Dr, Soetomo 